\title{
Refleksi Konsep Ketuhanan Agama Kristen dan Agama Islam dalam Pandangan Filsafat Perenial
}

\author{
Milton Thorman Pardosi ${ }^{1}$, Rr. Siti Murtiningsih ${ }^{2}$ \\ Universitas Gadjah Mada; Universitas Advent Indonesia \\ Universitas Gadjah Mada ${ }^{2}$ \\ e-mail: mtpardosi@gmail.com, stmurti@ugm.ac.id
}

\begin{abstract}
Agama Kristen dan Agama Islam adalah dua agama yang diturunkan oleh Allah, keturunan Abraham dan memiliki Kitab Suci yang diwahyukan Allah. Keduanya sama-sama mempercayai Allah Yang Maha Esa, Sang Pencipta. Tujuan penulisan ini untuk memahami konsep ketuhanan agama Kristen dan Islam dan memahami refleksi ketuhanan kedua agama tersebut dalam Filsafat Perenial. Dalam pemahaman agama Kristen, Allah itu Esa yang merujuk kepada kualitatif. Sementara kata Allah bukanlah nama Oknum yang disembah melainkan gelar karena kata "Allah" juga digunakan baik kepada sesembahan Bangsa Israel dan Non-Israel. Salah satu nama Allah dalam Alkitab adalah Yahweh. Sementara dalam pemahaman agama Islam, konsep Allah adalah Esa merupakan salah satu rukun iman (Tauhid) dan ini merujuk kepada kuantitatif. Konsep Esa ini adalah monoteisme murni, di mana Tuhan bukan hanya jumlahnya Esa melainkan sifatnya pun Esa. Perbedaan pemahaman ketuhanan kedua agama tersebut dapat dilihat melalui Filsafat Perenial di mana Filsafat Perenial merupakan metafisika yang mengakui realitas Ilahi yang substansial bagi dunia benda, hidup dan pikiran. Filsafat Perenial memberikan analog tentang Tuhan seperti cahaya matahari yang satu dan ketika ditangkap oleh prisma memunculkan beraneka macam warna. Itu sebabnya Filsafat Perenial melakukan dua pendekatan yaitu: Eksoteris yang berfungsi sebagai dasar pijakan pemahaman tentang Tuhan berdasarkan perkataan Tuhan tentang dirinya melalui wahyu; Pendekatan Esoterik adalah pemahaman langsung tentang Tuhan melalui penyatuan seluruh potensi kemanusiaan yang dikenal sebagai "jalan" mistik. Kesimpulannya, agama Kristen dan agama Islam adalah menyembah Allah yang sama yaitu Allah Yang Maha Esa, Sang Pencipta (Esoterik). Kedua, kata Esa, dalam pemahaman agama Kristen berarti kualitatif sementara dalam Agama Islam berarti kuantitaf (Eksoterik). Ketiga, kata Allah dipahami berbeda, yang satu sebagai gelar, namun bagi yang satu sebagai nama (Eksoterik).
\end{abstract}

Kata Kunci: Perenial, Allah, Esa

\begin{abstract}
Christianity and Islam are religions revealed by God, descendants of Abraham and have the Scriptures revealed by God. Both of them trust God Almighty, the Creator. The purposes of this paper are to understand the divine concepts of Christianity and Islam and understand the reflection of the divinity of them in Perennial Philosophy. In Christianity, God is One who refers to qualitative. While the word Allah is not the name of a Person who is worshiped but a title because the word "Allah" is used both by the Israelites and Non-Israelites. One of the names of God in the Bible is Yahweh. While in Islam, the concept of Allah is One as one of the pillars of faith (Tauhid) and this refers to quantitative. The Esa concept is pure monotheism, in which God is not only one in number but also in nature. The difference of the two religions can be seen through Perennial Philosophy in which Perennial Philosophy is a metaphysics that recognizes a substantial divine reality for the world of things, life and mind. Perennial philosophy provides an analogue of God like sunshine but when captured by a prism raises various colors. That is why Perennial Philosophy takes two approaches: Exoteric which serves as the basis for understanding God based on God's words about Him through revelation; The Esoteric approach is a direct understanding of God through the unification of all potential humanities known as the mystical "path." In conclusion, Christianity and Islam are worshiping the same God, Allah Almighty, the Creator (Esoteric). Second, the word Esa, in the understanding of Christianity means qualitative while in Islam means quantitative (exoteric). Third, the word Allah is understood differently, for Christianity as a title, but for Islam as a name (Exoteric).
\end{abstract}

Keywords: Perennial, Allah, One. 


\section{Pendahuluan}

Agama Kristen dan Agama Islam adalah dua agama besar di dunia yang sama-sama mengakui bahwa Kitab Sucinya diturunkan oleh Allah kepada para nabi dan rasul-Nya. Di dalam masing-masing Kitab Suci tersebut Allah menjelaskan Diri-Nya. Itu sebabnya, ketika berbicara tentang Allah, kedua agama tersebut akan menyatakan bahwa Allah itu "berada di atas, di langit, yang berbeda dengan penganut Hindu yang akan menunjukkan Tuhan berada dalam relung hatinya (Guha)" (Kuswanjono, 2006: 44). Agama Kristen dan agama Islam, termasuk agama Yahudi, dikelompokkan sebagai agama-agama semawi dan agama Abrahamik.

Terkait pemahaman Ketuhanan, agama Kristen dan agama Islam adalah agama Monoteis Teisme di mana "Tuhan itu ada, dan merupakan suatu realitas yang bersifat transenden dan mempunyai suatu maksud dan tujuan yang bersifat immanen" (Trueblood, 1965: 47). Teisme itu sendiri, menurut Trueblood (Trueblood, 1965: 47), adalah "kepercayaan bahwa Tuhan itu adalah Zat yang menciptakan alam dunia, akan tetapi tak terbatas dalam dunia ini. Tuhan adalah sesuatu Zat yang ada tersendiri dan tidak bersandar kepada pengetahuan kita terhadap-Nya. Sementara Monoteisme adalah "mengakui adanya satu Allah...mengakui adanya Allah yang berlainan dengan alam semesta. Karena sifat yang terakhir ini Allah disebut transenden, yakni yang melebihi alam semesta. Sebab demikianlah Allah dimengerti juga sebagai yang Maha Kuasa terhadap alam semesta alam ini, yakni sebagai penciptanya" (Huijbers, 1992: 26). Pada intinya, agama Kristen dan agama Islam percaya bahwa Allah itu ada (transenden dan Imanen) namun Esa.

Perbedaan pemahaman akan Tuhan dalam kedua agama tersebut meruncing dalam konsep Allah itu Esa. Agama Islam mengakui bahwa: "Tidak ada Tuhan selain Allah." Agama Kristen juga mengakui hal yang sama bahwa "Tidak ada Allah lain dari pada Allah yang Esa" (1 Korintus 8:4). Namun selain pengakuan tersebut, agama Kristen juga mengakui bahwa Yesus, Anak Allah, adalah Allah juga. Agama Kristen juga mengakui Roh Kudus sebagai salah satu dari tiga Oknum KeAllahan. Pemahaman seperti ini bagi agama Islam dianggap sebagai pengingkaran keberadaan Allah sebagai Allah yang Esa.

Melihat hal di atas, penulis melihat perlunya membahas konsep Ketuhanan agama Kristen dan agama Islam secara umum agar konsep ketuhanan kedua agama tersebut tidak lagi menjadi objek perdebatan melainkan dapat dipahami dengan baik dan benar. Oleh sebab itu rumusan masalah dalam makalah ini adalah: (1) Bagaimanakah pemahaman Ketuhanan agama Kristen secara umum?; (2) Bagaimanakah pemahaman Ketuhanan agama Islam secara umum?; (3) Bagaimanakah refleksi pemahaman Ketuhanan agama Kristen dan agama Islam dalam pandangan Filsafat Perenial?

Sementara tujuan penelitian dalam makalah ini adalah: (1) Untuk memahami konsep Ketuhanan agama Kristen secara umum; (2) Untuk memahami konsep ketuhanan agama Islam secara umum; (3) Untuk memahami refleksi pemahaman Ketuhanan agama Kristen dan agama Islam dalam Filsafat Perenial.

Sementara metode penelitian yang digunakan dalam penelitian ini adalah metode penelitian kualitatif yang penekanannya lebih pada segi kualitas secara alamiah karena menyangkut pengertian, konsep, nilai serta ciri-ciri yang melekat pada objek penelitian (Kaelan, 2005: 5). Adapun tujuan penelitian kualitas filosofis menurut Danim (Danim, 2002: 35) dimaksudkan menghasilkan ilmu-ilmu 'lunak' (soft sciences) di mana esensinya adalah sebagai sebuah metode pemahaman atas keunikan, dinamika, dan hakikat holistik dari kehadiran manusia dan interaksinya dengan lingkungan. Itu sebabnya dalam penulisan makalah ini, penulis menelaah pustaka

\section{Metode}

Metode yang digunakan dalam pengumpulan data ini adalah metode (library research) melalui penelaahan berbagai sumber ilmiah dalam bentuk buku-buku, literatur-literatur, dan artikel ilmiah yang sesuai dengan kajian yang dibahas dalam artikel.

\section{Hasil dan Pembahasan}

Dalam bagian ini dibahas konsep Ketuhanan agama Kristen dan agama Islam secara umum. Setelah itu dilanjutkan dengan pembahasan refleksi konsep Ketuhanan dari kedua agama tersebut. 


\section{Konsep Ketuhanan Agama Kristen}

Sumber utama dalam memahami Tuhan adalah Alkitab itu sendiri. Namun harus diakui bahwa pemahaman manusia akan Allah tetap saja terbatas karena Allah itu tak terbatas adanya dan kemungkinan besar pemahaman manusia pun bisa berbeda walau sumbernya sama.

Hal pertama menyangkut istilah Keallahan. Istilah "Trinitas" atau "Trinity" tidak ada di dalam Alkitab. Istilah yang ada adalah Keallahan (Divinity atau Godhead). Istilah Trinitas muncul sebagai hasil usaha manusia (gereja) memanahami Allah di dalam Alkitab. Ada beberapa ayat di dalam Alkitab yang menyatakan konsep keAllahan tersebut: (1) Dalam Kisah Para Rasul 17:29 yang berbunyi: "Karena kita berasal dari keturunan Allah, kita tidak boleh berpikir, bahwa keadaan ilahi (Godhead) sama seperti mas atau perak atau batu, ciptaan kesenian dan keahlian manusia." Kedua, dalam Kitab Roma 1:20 dinyatakan: "Sebab apa yang tidak nampak daripada-Nya, yaitu kekuatan-Nya yang kekal dan keilahian-Nya (divinity), dapat nampak kepada pikiran dari karya-Nya sejak dunia diciptakan, sehingga mereka tidak dapat berdalih." Dalam dua ayat di atas, istilah yang dipakai untuk "Ilahi" dalam bahwa Inggris adalah Godhead atau Divinity (Yunani: Theios).

Hal kedua adalah kata YAHWEH dan Elohim. Kata YAHWEH (diterjemahkan TUHAN) adalah nama Sang Pencipta Langit dan Bumi (Kejadian 1). Namun dalam pembacaannya sehari-sehari, orang Israel menggantinya dengan kata Adonay yang diterjemahkan "Tuan" (kalau merujuk kepada manusia) dan "Tuhan" (kalau merujuk kepada Oknum yang disembah). Alasan orang Israel melakukan hal ini adalah untuk menghindarkan diri dari penyebutan Nama Tuhan dengan sia-sia sesuai dengan perintah hukum ketiga dari 10 hukum Moral (Keluaran 20:7).

Kata elohim (diterjemahkan Allah atau God) bukanlah Nama Sang Pencipta. Elohim adalah gelar dari yang disembah oleh manusia termasuk Sang Pencipta itu sendiri. Oknum yang menciptakan langit dan bumi adalah Yahweh atau Yah atau Yehovah atau YHWH. Alkitab menuliskan: "Namanya ialah TUHAN (Yahweh atau Yah)" (Mazmur 68:5 [ayat 4 dalam Bahasa Inggris]). Nabi Yeremia juga mencatatkan hal yang sama: "Yahweh atau Yah (TUHAN) ialah nama-Nya" (Yeremia 33:2).

Kata elohim itu sendiri dipakai baik kepada oknum yang disembah oleh bangsa-bangsa non-Israel dan Israel. Ini dapat dilihat dari penggunaan kata elohim (Allah) di dalam Perjanjian Lama. Contohnya, (allah) elohim orang Amori (Yosua 24:15), allah (elohim) negeri Hamat dan Arpad (Yesaya 36:19); allah (elohim) negeri sefarwaim (Yesaya 36:19), allah (elohim) dari bangsa-bangsa Gozan, Haran, Rezef, bani Eden yang di Telasar (Yesaya 37:12), dll. Allah (elohim) yang disembah bangsa Israel juga disebut menurut nama bangsa Israel: TUHAN Allah (Yahweh Elohim) Israel (Yosua 10:42; Ezra 6:21; 9:5; 1 Raja-raja 11:9); TUHAN Allah (Yahweh Elohim) Ibrani (Keluaran 3:18; 5:3).

Hal ketiga menyangkut Keesaan Allah. Ada banyak ayat-ayat di dalam Kitab Suci yang menjelaskan tentang Keesaan Allah seperti: "Tidak ada yang lain kecuali TUHAN (Yahweh) Allah" (Ulangan 4:35); "TUHANlah (Yahweh) Allah yang di langit di atas dan di bumi di bawah, tidak ada yang lain" (Ulangan 4:39); "TUHAN (Yahweh) itu Allah (Elohim) kita dan TUHAN (Yahweh) itu Esa (echad)" (Ulangan 6:4). Pernyataan keesaan Allah ini disebut dengan Shema (pernyataan iman orang Israel yang diucapkan paling tidak dua kali dalam sehari melalui doadoa mereka kepada Allah).

Sementara di dalam Perjanjian Baru, beberapa ayat yang menyatakan Keesaan Allah adlaah: (1) "Tuhan itu Esa" (Markus 12:29); "Allah adalah satu-satunya yang benar" (Yohanes 17:3); (3) "Allah yang Esa, Satu Allah yaitu Bapa, dan satu Tuhan yaitu Yesus Kristus" (1 Korintus 8:4-6); (4) Efesus 4:4-6 "Satu Roh, Satu Tuhan, Satu Allah" (Efesus 4 :4-6) ; (5) "Allah itu Esa" (1 Timotius 1 :17); "Allah itu Esa, dan Esa pula Pengantara kita" (1 Timotius 2:5).

Kata "Esa" yang dimaksudkan di sini bukanlah dalam pengertian matematika yaitu angka satu (kuantitas), melainkan prinsip atau konsep kesatuan (kualitas). Kata "Esa" (echad) dalam pemahaman Perjanjian Lama adalah adjective of quality (kata sifat kualitas). Kata ini fokus kepada unity (kesatuan), uniqueness (keunikan), dan monoteisme (Jenson, 1997: 350). Sementara kata "Esa" dalam bahasa Yunani adalah eis. LXX (Septuagint) menerjemahkan Ulangan 6:4 untuk kata echad dengan eis: [The] Lord our God is one [eis] Lord. Di Perjanjian Baru kata eis yang berkaitan dengan KeAllahan bisa diterjemahkan "Esa" (Markus 12:29; 1 Timotius 2:5) dan juga "satu" (Yohanes 10:30; Galatia 3:20).

Kata "Esa" atau "satu" dalam bahasa Ibrani juga digunakan untuk menggambarkan bahwa pria dan wanita yang sudah dipersatukan dalam perkawinan adalah esa (Kejadian 2:24). 
Nabi Musa sebenarnya bisa menggunakan kata yachid yang berarti "hanya satu" baik di dalam Ulangan 6:4 dan Kejadian 2:24, tetapi Roh Kudus tidak menuntunnya untuk melakukan itu sebagaimana yang Musa gunakan untuk menyatakan Ishak sebagai anak tunggal (yachid) Abraham (Kejadian 22:2,12,16). Sesuatu dinyatakan dengan jelas di sini tentang sifat dasar Allah (nature of God) yaitu kesatuan dari elemen atau pribadi yang berbeda (a unity of distinct parts or elements).

Hal keempat adalah bahwa Oknum KeAllahan lebih dari satu. Alkitab menyatakan bahwa KeAllahan itu lebih dari satu pribadi. Beberapa ayat yang menyatakan hal tersebut dalam Perjanjian Lama: (1) "Baiklah Kita menjadikan manusia menurut gambar dan rupa Kita" (Kejadian 1:26). Di sini, salah satu Oknum KeAllahan mengajak Oknum keAllahan lainnya dalam penciptaan dunia dan manusia (band. dengan Kejadian 3:22 dan 11:7); (2) "Tuhan Allah (Bapa) mengutus aku (Anak Allah) dengan Roh-Nya (Roh Kudus) (Yesaya 48:16; band. dengan Yesaya 42:1).

Sementara di Perjanjian Baru ayat-ayat yang menyatakan bahwa Oknum KeAllahan itu lebih dari satu Pribadi adalah: (1) Ketika Yesus dibaptiskan, maka ketiga Oknum KeAllahan: Bapa, Anak, dan Roh Kudus hadir bersama-sama (Matius 3:13-17); (2) Dalam formula baptisan, maka seseorang harus dibaptiskan dalam nama Bapa, Anak, dan Roh Kudus (Matius 28:19,20); (3) Yohanes Kekasih dalam Yohanes 1:1-3 memberikan penjelasan tentang Yesus dan Allah bahwa keduanya adalah dua Oknum KeAllahan yang berbeda; (4) "Aku dan Bapa adalah Satu" (Yohanes 10:30). Kata Yunani yang digunakan adalah Eis. Di sini dinyatakan bahwa Yesus setara dengan Bapa (I and My Father are One [Dua Subyek]).

Singkatnya, Yesuslah yang menjelaskan bahwa Oknum KeAllahan itu lebih dari satu. Huston Smith (Smith, 1995: 389) meringkaskannya sebagai berikut: Walaupun Tuhan itu Esa, la juga tiga. Yesus menyatakan bahwa la dan Tuhan adalah satu (Yohanes 10:30). Yesus juga menyebut adanya pihak ketiga dalam Ketuhanan tersebut: "Aku akan meminta kepada Bapa, dan la akan memberimu seorang penolong yang lain, yaitu Roh Kudus, sehingga la akan besertamu selama-lamanya (Yohanes 14:16).

Hal kelima berkaitan dengan Yesus adalah Allah. Ada beberapa ayat yang menyatakan bahwa Yesus itu adalah salah satu dari Oknum Keallahan. Pertama, pernyataan Bapa dalam Matius 3:17 yang berkata: "Inilah Anak-Ku yang kukasihi, kepada-Nyalah Aku berkenan." Di sini Bapa mendeklarasikan bahwa yang dibaptis oleh Yohanes Pembaptis adalah Anak Allah. Konsep "Anak" dan "Bapa" bukanlah konsep manusia lahiriah; tetapi rohaniah. Allah tidak pernah beranak karena ia tidak memiliki istri. Kedua, pernyataan malaikat Allah dalam Lukas 1:35 yang berbunyi: "Roh Kudus akan turun atasmu dan kuasa Allah Yang Maha Tinggi akan menaungi engkau; sebab itu anak yang akan kau lahirkan itu akan disebut kudus, Anak Allah." Selanjutnya pernyataan dari Setan yang dicatat dalam Matius 8:29 yang berbunyi: "Apa urusanMu dengan kami, hai Anak Allah? Adakah Engkau ke mari untuk menyiksa kami sebelum waktunya." Setan mengenal betul siapa Yesus Kristus. Setan mengetahui bahwa hanya Anak Allah, Yesus Kristus yang bisa membinasakan mereka. Keempat, pernyataan Yesus sendiri yang dicatat dalam Matius 26:63,64 yang berbunyi: "Demi Allah yang hidup, katakanlah kepada kami, apakah engkau Mesias, Anak Allah, atau tidak. Jawab Yesus, Engkau telah mengatakannya. Akan tetapi, Aku berkata kepadamu, mulai sekarang kamu akan melihat Anak Manusia duduk di sebelah kanan Yang Maha Kuasa dan datang di atas awan-awan." Kelima, Yesus berkata bahwa pada waktu proses penghakiman terhadap diri Yesus sebelum disalibkan, Imam besar meminta kepastian dari Yesus tentang apakah Dia adalah Anak Allah. Yesus menjawab lebih dari sekedar jawaban ya atau tidak. Imam besar menyatakan bahwa jawaban Yesus adalah menghujat Allah. Matius 27:43 "Karena la telah berkata: Aku adalah Anak Allah" (band. Yohanes 10:36).

Verkuyl (Verkuyl, 1961: 83) menjelaskan tentang Yesus adalah gambar Allah. Allah melarang manusia membuat patung atau apapun yang menggambarkan Dia. la telah memberikan kepada manusia "gambar-Nya" sendiri yaitu Yesus Kristus. Yesus Kristus, Anak Bapa, yang ada dalam pangkuan Bapa, yang mengambil wujud seorang manusia dan datang ke antara kita, Dialah gambar Allah (2 Korintus 4:4; Kolose 1:15). Anak Allah setara dengan Allah tetapi la merendahkan diri-Nya dan mengambil wujud seorang manusia. Yesuslah yang menyatakan kepada manusia siapa Allah itu. Di dalam Yesus berdiam secara jasmaniah seluruh kepenuhan Allah (Kolose 2:9).

Selanjutnya akan dijabarkan secara sederhana konsep ketuhanan beberapa Filsuf Kristen. Arqom Kuswanjono (Kuswanjono, 2006: 51-53) menyimpulkan beberapa konsep ketuhanan dari para filsuf Kristen: Pertama, Agustinus (354-430 M) menyatakan bahwa Tuhan tidak membuat keburukan, keburukan bukanlah sesuatu yang dibuat, namun keburukan hanya 
karena tidak adanya kebaikan. Tuhan adalah pengada yang mutlak; abadi, tidak berubah. Dia berada di luar pemahaman manusia karena lebih besar dari segala sesuatu. Tuhan itu berpribadi, berpikir, dan berkehendak. Dia menciptakan dunia dan mengendalikannya sesuai dengan rencana Ilahi-Nya. Tuhan menciptakan dunia dari ketiadaan. Kedua, Duns Scotus Eurigena (810-877 M) memberikan dua pendekatan mengenai Tuhan yaitu: Pendekatan Positif, di mana dinyatakan bahwa "Tuhan adalah bijaksana" merupakan pernyataan yang sah karena memang demikian halnya. Lalu Pendekatan Negatif, di mana dinyatakan bahwa "Tuhan tidak bijaksana" karena pernyatan ini menunjukkan bahwa Tuhan lebih dari sekedar bijaksana. Tuhan bukanlah merupakan salah satu dari semua yang ada, namun Dia lebih dari sekedar semua yang ada. Pada hakekatnya, Tuhan itu "bukan apa-apa." Dia bukan merupakan objek. Dia tidak memiliki "keberadaan" dalam pengertian tertentu. Cara berada Tuhan berbeda dengan cara berada manusia. Akan tetapi jika Tuhan "bukan apa-apa," Dia juga merupakan "segala sesuatu." Ini berarti Tuhan semata yang memiliki eksistensi sejati.

Pemikiran Anselmus (1033-1109 M) menyatakan bahwa: Tuhan bukannya "bukan apaapa" melainkan adalah Pengada Tertinggi dari segala sesuatu. Tuhan bukan hanya dapat diketahui di dalam iman. Untuk mengetahui Tuhan, orang harus melibatkan diri di dalam Tuhan. Aku beriman agar aku mengerti (credo ut intelligam). Tuhan adalah sesuatu yang selainnya sesuatu yang lebih besar tidak dapat dipikirkan (aliguid quo nihil maius cogtari possit). Tuhan itu harus bereksistensi, karena tanpa eksistensi, Tuhan tidak akan menjadi sempurna. Eksistensi lebih sempurna daripada tidak bereksistensi. Terakhir adalah Thomas Aquinas (1225-1274) yang menyatakan bahwa Tuhan adalah sebab utama dari segala urusan. Dia adalah kesempurnaan akhir, norma kebenaran, keindahan, kebaikan, perancang tertib alam semesta, pemberi, dan pengaruh yang cerdas. Pengetahuan manusia tentang Tuhan mengimplikasikan bahwa Dia sebagai satu-satunya pengaruh yang mutlak, yang tidak bergerak dan tidak berubah. Aquinas menyampaikan dua cara memahami Tuhan: cara negatif, menunjukkan gambaran Tuhan, bahwa Tuhan tidak tersusun, tidak terbilang, tidak musnah, dan tidak kurang. Kedua, cara analog, yang didasarkan kepada kemiripan. Meskipun tidak sama dengan siapapun atau apapun, Tuhan memiliki beberapa kemiripan atau persamaanpersamaan. Ini terjadi karena fakta bahwa Dia adalah penyebab dari segala sesuatu dan akibat secara niscaya memiliki persamaan dengan sebabnya.

\section{Konsep Ketuhanan Agama Islam}

Islam adalah nama agama yang diwahyukan oleh Tuhan untuk manusia (Surat 3 ayat 67) di mana dikatakan bahwa "Ibrahim bukan orang Yahudi, bukan orang Nasrani, akan tetapi orang yang mengikuti jalan lurus (hanifan) dan orang Muslim (musliman) dan ia bukan orang musyrik" (Rasjidi, 1974: 98). Adapun pokok-pokok ajaran dari Nabi Muhammad SAW tentang Allah adalah: (1) Tuhan tidak beranak dan tidak diperanakkan; (2) Allah itu Esa (3) Allah itu tempat meminta; (4) Tidak satupun yang serupa dengan Dia (Rasjidi, 1974: 100).

Agama Islam sendiri memiliki Enam Rukun Iman yaitu: Percaya kepada Allah Yang Maha Esa (Tauhid); Percaya pada malaikat-malaikat; Percaya pada kitab-kitab Suci; Percaya pada rasul-rasul Allah; Percaya pada hari akhir atau Yaumul (kiamat) dan Qadar; Percaya pada Qadar baik dan buruk berasal dari Tuhan (Rasjidi, 1974: 102). Kalimat Syahadat dan rukun iman pertama adalah dasar konsep ketuhanan agama Islam.

Hal pertama yang akan dijelaskan adalah konsep ketuhanan beberapa tokoh agama Islam. Penulis meringkaskan beberapa pendapat para ahli agama Islam yang diringkaskan oleh Muhammad as-Shadiqi: Pertama, datang dari Imam Ali Bin Abi Thalib yang merupakan murid pertama Rasullulah sekaligus orang yang paling mirip dengan Sang Rasul, saudara, pendamping, penasihat, dan khalifah keempat yang memiliki jiwa yang suci. la adalah orang yang paling alim dan paling adil di kalangan umat Islam setelah wafatnya Rasul. la menyatakan: "Allah tidak bernama, tidak berjism, tidak menitis kepada sesuatu, tidak berupa, tidak berbentuk, tidak ada yang menyerupai-Nya, tidak terbatas, tidak berposisi dan tidak bertempat, tidak dapat dipertanyakan dengan pertanyaan "bagaimana?, tidak terikat pada suatu tempat, tidak berada di satu tempat, tidak penuh dan tidak juga kosong, tidak berdiri, tidak duduk, tidak diam dan tidak juga bergerak, tidak gelap dan tidak juga terang, tidak berbentuk ruh dan tidak juga berbentuk jiwa, tidak terlepas dari posisi tertentu, tidak berwarna, tidak terdetik dalam hati manusia dan tidak dapat tercium melalui bau tertentu (As-Shadiqi, 2003: 320); Kedua, oleh Al Imam Abi al Hasan al Ridla yang merupakan khalifah Rasulullah yang kedelapan dan termasuk orang yang ma'shum (terpelihara dari dosa) di mana konsep Ketuhanannya adalah: "Walaupun Dia memiliki suatu dimensi, namun keberadaan-Nya adalah wajib karena adanya dimensi tersebut, atau bahkan mendahului dimensi, karena adanya 
dimensi tersebut karena sifat qidam Tuhan" (As-Shadiqi, 2003: 332). Selanjutnya disampaikan bahwa "Dialah sang Pencipta segala dimensi, sehingga Dia tidak terikat dengannya. Dialah yang menjadikan sumber segala metode, sehingga Dia tidak terikat dengannya. Maka Dia tidak dapat diketahui dengan dimensi manapun, atau dengan metode apapun, termasuk dengan indera serta tidak dapat dipersamakan dengan apapun" (As-Shadiqi, 2003: 320); Sementara argumentasi ketiga datang dari AI Imam Ja'far ibn Muhammad al Shadiq yang merupakan Imam ke-6 dalam tradisi Syi'ah. Dalam pemahamannya, Tuhan "dapat mendengarkan perkataan dan mengetahui segala rahasia mereka, tidak ada tempat yang tidak diketahui-Nya, tidak terbatas oleh tempat-tempat tertentu dan tidak ada tempat yang tidak dapat dijangkau-Nya. Dia dapat diketahui dengan bukti-bukti kebesaran-Nya. Dialah yang mengutus Muhammad SAW, dengan membawa ayat-ayat yang jelas dan bukti-bukti yang terang serta mensyariatkan ibadah ini kepada kita" (As-Shadiqi, 2003: 334).

Baharudin (Baharudin, 2014: 42) memberikan kesimpulan berkaitan dengan Allah yang Esa, Transenden dan Imanen menurut ayat-ayat suci Al-Quran sebagai berikut: "Dalam agama Islam kejelasan tentang Tuhan adalah Esa, sekaligus transenden dan imanen terdiskripsi dalam beberapa ayat Al-Quran, antara lain Qul Huwa Allah Ahad. Artinya 'katakanlah wahai Muhammad, Dia (Allah) adalah satu' (Surat 112 ayat 1). Transendensi Tuhan terdeskripsi dalam Surat Al-A'raf ayat 54, yang artinya "sesungguhnya Tuhan kamu adalah Allah yang telah menciptakan langit dan bumi dalam enam masa, lalu Dia bersemayam di atas 'Arsy.' Imanensi Tuhan terdeskripsi dalam Surat Qaf ayat 16, yang artinya, 'dan sesungguhnya kami telah menciptakan manusia dan mengetahui apa yang dibisikkan oleh hatinya, dan kami lebih dekat kepadanya dari pada urat lehernya.' Adapun ayat yang sekaligus menunjukkan bahwa Tuhan disamping transenden dan imanen adalah Surat Yunus ayat 3, yang artinya, "sesungguhnya Tuhan kamu adalah Allah yang menciptakan langit dan bumi dalam enam masa, kemudian Dia bersemayam kemudian bersemayam di atas 'Arsy' untuk mengatur semua urusan."

Hal kedua adalah Konsep Tauhid. Tauhid adalah dasar agama Islam. Kalau seseorang mau menjadi pemeluk agama Islam, maka ia harus mulai meyakini Allah. Dalam pemahaman agama Islam, Tuhan itu Esa (Satu). Setiap pemeluk agama Islam yakin akan Allah. Gazalba (Gazalba, 1976: 19) menyatakan bahwa "Keyakinan akan Allah, keyakinan akan Tuhan Yang Maha Esa, jadi pangkal dari sistematika keyakinan dan kepercayaan, selanjutnya asas dari seluruh ajaran Islam. Kalau Tauhid lemah, sistematika dan asas itupun tidak kokoh."

Ketuhanan Yang Maha Esa bagi agama Islam lahir bukan karena hasil usaha manusia dalam memahami Allah. Itu juga bukan ujung dari evolusi konsep Ketuhanan yang ada pada manusia. Agama Islam meyakini (Gazalba, 1976: 21) bahwa: Pertama, ini adalah wahyu yang diturunkan Allah kepada manusia (Rasul-Nya); Kedua, Ketuhanan yang Maha Esa adalah bentuk monoteisme murni; Ketiga, Tuhan bukan saja jumlahnya yang esa, tapi sifat-Nya pun esa; keempat, Sifat-sifat yang ada pada Tuhan adalah satu-satunya. Tidak ada duanya. Tidak ada satupun yang memiliki sifat seperti Tuhan. Selanjutnya Tuhan juga esa dalam perbuatan. Perbuatan terjadi karena adanya kuasa (qudrat), kehendak (iradat) dan pengetahuan (ilm), yaitu sifat Ma'ani ke 7,8 dan 9. Perbuatan Allah esa, satu-satunya, tidak ada duanya, tidak ada yang menyamai, menyerupai dan menandingi (Gazalba, 1976: 23,24).

Al-Akkad menuliskan bahwa "Pikiran ketuhanan dalam Islam adalah 'fikiran yang sempurna' di mana satu segi mengalahkan segi yang lain, dan tidak memperbolehkan tertimpa oleh sifat-sifat syirik dan pemiripan (dengan makhluk) juga tidak membuat perbandingan bagi Allah menurut indera maupun menurut hati, melainkan baginya adalah 'perumpamaan (contoh) yang paling tinggi' dan 'tidak ada sesuatu yang sepertinya'” (Al-Akkad, 1981: 111). Beberapa bukti dari Kitab Suci Al-quran adalah: Surat Al-An'am ayat 163; Surat Al-Furqan ayat 2; Surat Al-A'raf ayat 190; Surat Yunus ayat 18,38; Surat Al-Jin ayat 2.

Hal selanjutnya yang akan dibahas adalah konsep ketuhanan beberapa Filsuf Islam. Arqom Kuswanjono (Kuswanjono, 2006: 56-60) menyimpulkan beberapa konsep Ketuhanan para filsuf Islam yang terkenal: Pertama, Al Kindi (801-873 M) yang menyatakan: Allah bersifat tetap, tunggal, gaib dan penyebab sejati gerak. la tunggal sehingga tak dapat dipecah-pecah lagi menjadi lebih tunggal. la tak terlihat, karena la tak tersusun dan tak ada susunan bagi-Nya tetapi sesungguhnya la terpisah dari segala yang dapat dilihat, karena la...adalah penyebab gerak segala yang dapat dilihat. Penciptaan dari ketiadaan adalah hak istimewa Tuhan. la bukan materi, tak terbentuk, tak berjumlah, tak berkualitas dan tak berkejadian. la abadi oleh karena la Maha Esa; Sementara menurut Al Farabi (870-950 M) Allah Esa, tidak bergerak, bahwa la menjadi sebab yang aktif bagi semua yang ada, bahwa la mengatur alam ini dengan kemurahan, kebijaksanaan dan keadilan. Tuhan adalah pertama dari segala sesuatu yang ada. Tuhan tidak serta merta memutuskan untuk menciptakan dunia, karena jika demikian maka 
Tuhan akan bersifat abadi dan statis; Ketiga, Ibnu Sina (980-1037 M) yang menyatakan bahwa Tuhan adalah pusat dan sumber eksistensi. Segala yang ada secara eksistensial berasal dari Tuhan. Kesempurnaan eksistensi dapat dicapai hanya oleh para nabi dan kekasih Allah. Terakhir, Al Ghazali (1058-1111 M) yang menawarkan cara untuk memahami Tuhan dengan metode mistik. Akal manusia tidak cukup memadai untuk memahami Tuhan. Disiplin mistik menghasilkan perasaan langsung dan intuitif sehingga menemukan pemahaman yang lebih koprehensif. Melalui pengalaman mistiklah jalan satu-satunya untuk melakukan verifikasi terhadap realitas yang terletak di luar jangkauan intelek manusia. Realitas yang disebut "Tuhan" terletak di luar kawasan persepsi indera dan pemikiran logis, sehingga ilmu dan metafisika tidak dapat membuktikan wujud Tuhan. Kaum muslimin tidak pernah lagi membuat asumsi mengenai Tuhan sebagai pengada yang eksistensinya dapat dibuktikan secara ilmiah atau secara filosofis.

Refleksi Pemahaman Ketuhanan Agama Kristen dan Agama Islam dalam Filsafat Perenial

Kata "Perenial" berasal dari bahasa Latin perennis yang berarti kekal, selama-lamanya, abadi (Kuswanjono, 2006: 10). Filsafat Perenial dikenal juga sebagai Filsafat Keabadian yaitu "pengetahuan mistis universal yang telah ada dan akan selalu ada selamanya" (Kuswanjono, 2006: 10). Menurut Kuswanjono (Kuswanjono, 2006: 10), Filsafat Perenial "merupakan metafisika yang mengakui realitas llahi yang substansial bagi dunia benda, hidup dan pikiran. Ini juga merupakan psikologi yang menemukan sesuatu yang sama di dalam jiwa dan bahkan identik dengan realitas ilahi serta merupakan etika yang menempatkan tujuan akhir manusia pada pengetahuan 'dasar' yang imanen maupun transenden dari segala yang ada." Atau sebagaimana yang disampaikan oleh Charles Schimitt yang dikutip oleh Saputra (Saputra, 2012: 49), Filsafat Perenial berarti "filsafat yang tetap bertahan sepanjang zaman dan kesejatiannya dapat dipancarkan terhadap satu generasi ke generasi berikutnya serta mampu melewati kecenderungan pola filsafat yang silih berganti."

Sederhananya, menurut Utomo (Utomo, 2012: 81) Filsafat Perenial percaya akan adanya sumber yang sama pada setiap tradisi dan agama. Itu sebabnya semua agama memiliki metafisika yang satu. Kepercayaan ini tentu juga membawa pengaruh dalam melihat persoalan ketuhanan yang ada di dalam setiap agama karena sumber segala sesuatu hanya satu. Oleh sebab itu Saputra (Saputra, 2012: 47) menyatakan bahwa keberadaan Filsafat Perenial sangatlah penting dalam memahami kompleksitas agama-agama dan keterlibatannya dalam berbagai macam persoalan kemanusiaan dewasa ini. Ini adalah cara pandang filsafat keagamaan yang bisa menjelaskan segala problema dan kejadian yang memerlukan kearifan dalam menjalankan dan memenuhi kewajiban hidup yang benar. Dengan kata lain, Filsafat Perenial adalah hakikat paling dalam dari agama-agama manusia.

Di sini yang lain, Filsafat Perennial menawarkan sebuah paradigma alternatif supaya manusia kembali kepada akar-akar spiritualitas dirinya tanpa tenggelam dalam gemerlap kehidupan materi yang seringkali membuat manusia khilaf dan menimbulkan berbagai tindakan yang tidak sesuai dengan kemanusiaan itu sendiri (Saputra, 2012: 52). Namun pada saat yang sama, Filsafat Perennial mempertahankan agama-agama formal dan berusaha terus mencari titik temu dalam masalah-masalah spiritual yang bersifat transenden dan esoterik. Ini dikarenakan dalam setiap agama dan tradisi-tradisi esoterik ada suatu pengetahuan dan pesan keagamaan yang sama, yang muncul melalui beragam agama dan dibungkus dalam berbagi bentuk dan simbol (Saputra, 2012: 52).

Di dalam memahami agama, menurut Kuswanjono (Kuswanjono, 2006: 4) Filsafat Perenial mengakui bahwa agama memiliki satu bentuk dan satu substansi. Substansi itu sendiri mempunyai hak yang tidak terbatas, sebab lahir dari Yang Mutlak sementara bentuk adalah relatif dan karena itu hak-haknya terbatas. Selanjutnya Kuswanjono (Kuswanjono, 2006: 4) menuliskan bahwa kaum Perenis berpendapat bahwa Kebenaran Mutlak (The Truth) hanyalah satu, tidak terbagi, tetapi dari yang satu ini memancarkan berbagai kebenaran (truth) yang berpartisipasi dan bersimbiose dengan dialektika sejarah, sehingga bentuk dan bahasa keagamaan juga mengandung muatan nilai budaya yang berbeda dari suatu kamunitas lain.

Analogi yang digunakan dalam memahami pemikiran Filsafat Perenial sebagaimana yang dijelaskan oleh Kuswanjono (Kuswanjono, 2006: 77) adalah analog tentang Yang Mutlak (Tuhan) seperti halnya cahaya matahari yang satu dan ketika ditangkap oleh prisma memunculkan beraneka macam warna. Setiap warna satu dengan yang lain adalah sebagai pancaran atau bagian dari 'yang satu' yang tidak dapat mengklaim bahwa dirinya adalah Yang Mutlak, ia hanyalah secara relatif mutlak. Dalam analogi ini, semua warna berasal dari 'yang 
satu' sebagaimana agama berasal dari Yang Satu, namun ketika ditangkap oleh sejarah dan kebudayaan memunculkan berbagai warna yang berbeda-beda.

Namun Filsafat Perenial bukan berarti ingin menyamakan semua agama atau hendak menciptakan suatu agama universal, akan tetapi justru membuka jalan menuju pendakian spiritual melalui penghidupan kembali tradisi-tradisi keagamaan yang berkembang dalam setiap agama. Sistem filsafat ini mencoba mencari titik temu (common platform) dalam menelusuri mata rantai historis tentang pertumbuhan agama, mencari esensi esoterik dari pluralitas eksoterik pada masing-masing agama yang ada (Kuswanjono, 2006: 5).

Oleh karena itu, Filsafat Perenial "mengakui setiap tradisi sakral sebagai sesuatu yang berasal dari surga atau asal llahiah yang harus dihargai dan diperlakukan dengan hormat. Tujuannya agar manusia tidak hanya merasa memiliki agama (having religion) dan melakukan ritual agama (doing religion) tetapi lebih jauh manusia dapat 'menjadi' beragama (being religion) dengan salah satu aplikasinya pada hidup bersama dalam keberagaman agama (living together among religions)" (Kuswanjono, 2006: 4).

Dalam pemikiran Filsafat Perenial, ada dua cara pendekatan seperti yang disampaikan oleh Kuswanjono (Kuswanjono, 2006: 8): pertama, pendekatan Eksoteris yang berfungsi sebagai dasar pijakan pemahaman tentang Tuhan berdasarkan perkataan Tuhan tentang DiriNya sendiri yaitu melalui wahyu. Areanya meliputi: ritual, tradisi, persepsi moral dan bidang intuisi. Kedua, Pendekatan Esoterik yaitu pemahaman langsung tentang Tuhan melalui penyatuan seluruh potensi kemanusiaan yang dikenal sebagai 'jalan' mistik. Areanya meliputi hikmah transendental dan kesatuan mistik, kesadaran yang bersumber dari pengetahuan secara langsung.

Istilah tentang Tuhan yang digunakan dalam Filsafat Perenial adalah "Realitas Ultim;" Realitas Absolut; Yang Satu untuk menghindarkan kesalahan yang mungkin terjadi dalam penamaan Tuhan (Kuswanjono, 2006: 84). Adapun lima kategori Realitas Ultim (Kuswanjono, 2006: 84) adalah: (1) Sebelum adanya kultur dan agama yang mengajarkan keesaan Tuhan, setiap Tuhan merupakan Tuhan lokal, dengan nama diri yang juga lokal. Dengan demikian mengetahui Tuhan berarti mengetahui nama-Nya, sebaliknya mengetahui nama-Nya berarti mengetahui Tuhan; (2) Pluralitas Tuhan itu hanya dalam pengertian nama. Meskipun setiap nama menunjukkan pada satu Tuhan, tetapi dalam hal ini tidak berarti politeisme; (3) Banyaknya nama Tuhan harus dipandang hanya dalam pengertian manifestasi-Nya. Setiap nama Tuhan tidak akan membuat lemah sifat ketuhanannya, karena semua nama-nama Tuhan tersebut merujuk kepada sifat ketuhanan; (4) Nama-nama Tuhan yang banyak itu sebenarnya bukan nama Tuhan yang sebenarnya. Nama Tuhan yang sebenarnya justru tersembunyi dan rahasia; (5) Esensi dari nama Tuhan itu tidak bisa diketahui.

Adapun beberapa pendekatan yang ada dalam Filsafat Perennial sebagaimana yang diringkaskan oleh Saputra (Saputra, 2012: 56) adalah: Pendekatan Ontologis yaitu membahas tentang adanya dan menjelaskan adanya sumber dari segala yang ada (Being Qua Being), bahwa segala wujud sesungguhnya bersifat relatif, ia tidak lebih sebagai jejak, kreasi, atau cerminan dari Dia yang Esensi dan Substansinya di luar jangkauan nalar manusia. Dalam pendekatan Ontologis, manusia hanya sanggup menangkap bayang-bayangnya ataupun mencoba mendefinisikan lewat sifat dan nama-nama-Nya, tetapi tidak mungkin nalar manusia mampu membuat batasan atau definisi tentang Dia karena definisi itu sendiri sesungguhnya berarti batasan.

Pendekatan kedua (Saputra, 2012: 56) adalah pendekatan epistemologis yang membahas tentang makna dan substansinya serta segala proses terhadap manusia. Pendekatan ini membuka jalan menuju pencapaian kepada Yang Absolut melalui pendekatan mistik, yaitu melalui intelek yang lebih tinggi dalam memahami secara langsung tentang Tuhan. Ini terjadi tidak hanya melalui perenungan semata tetapi menggunakan sarana-sarana yang telah ada di setiap agama yang berupa ritus-ritus, simbol-simbol maupun tradisi-tradisi yang secara esensi berasal dari Yang Satu.

Selanjutnya adalah Pendekatan Psikologis (Saputra, 2012: 57) yaitu pendekatan yang menggali benih keimanan yang tertanam dalam hati manusia. Pendekatan ini berusaha mengungkapkan apa yang disebut "wahyu batiniah," "agama asli," "hikmah khalidah," "kebenaran abadi," "Sophia perennis" yang terukir dalam lembaran hati seseorang yang paling dalam yang senantiasa rindu pada Tuhan dan senantiasa mendorong seseorang berpikir dan berperilaku yang benar. Ini terjadi karena didapati bahwa dalam diri setiap orang terdapat atman yang pada dasarnya merupakan pancaran dari Brahman, atau dalam bahasa Alkitab: "Manusia itu diciptakan menurut gambaran Tuhan." 
Seluruh agama mempunyai esoterik ketuhanannya masing-masing. Saputra (Saputra, 2012: 123) meringkaskannya sebagai berikut: Agama Hindu, sebagaimana yang tertulis dalam Kitab Bhagavad Gita, meyakini bahwa Tuhan (Brahma) merupakan pencetus pertama dan sebagai yang awal di alam ini namun secara pasti sulit memahami siapa Dia sebenarnya. Semua agama yang dianut manusia seperti jalan-jalan yang akan mengantarkan mereka kepada Tuhan dan semua akan diterima-Nya. Buddhisme dan Taoisme meyakini adanya pengetahuan tertinggi yang dapat mempertemukan dan menyatukan berbagai agama meskipun kedua agama ini tidak pernah mempersoalkan Tuhan dalam pengertian sebagai yang Personal (Saputra, 2012: 123).

Sementara agama Yahudi melihat pencerahan merupakan puncak pengalaman mistik dalam Kabbalah. Pencerahan ini mengarah kepada penyatuan alam dengan Tuhan. Penyatuan sebagai puncak spiritual para mistikus ini telah melampaui atau tidak terikat dengan bentuk-bentuk formal agama (Saputra, 2012: 123). Bagi agama Kristen, ajaran mistikal tentang penyatuan seorang pencinta (lover) dengan Yang Dicintai (beloved) terdiri dari tiga jalan yaitu: Penyucian (the way of purgation); Jalan lluminasi (the way of illumination); Jalan Kesatuan (The way of union) (Saputra, 2012: 124).

Selanjutnya bagi agama Islam, sebagaimana yang diringkaskan oleh Saputra (Saputra, 2012: 125-126), ada beberapa tokoh yang menyatakan pendiriannya tentang esoterik agama. Pertama Ibnu Taimiyah yang menyatakan bahwa Hukum Taurat tidak dihapuskan oleh Injil dan Al'Quran. Demikian pula hukum Injil juga tidak dihapuskan oleh Al'Quran. Kedua, Thaha Husein yang mengatakan bahwa agama-agama ada kesamaan substansi pada level aqidah. Agama-agama semawi tersebut memiliki titik temu dalam level tauhid dan berasal dari sumber yang sama yaitu Tuhan. Terdapat kesamaan ajaran tentang sistem nilai-nilai universal yang disampaikan oleh setiap agama semawi. Ketiga, Abul Kalam Azad yang menyatakan bahwa agama tetap satu dan syariah berbeda-beda (al din wahid wa al Syariat Mukhtalifah; no Difference in Din, difference only in Sharia). Petunjuk Tuhan tetap sama disampaikan kepada manusia. Pesannya adalah: manusia harus beriman kepada Tuhan Yang Maha Esa dan berbuat baik sesuai dengan tingkat iman masing-masing.

Sebagai kesimpulan akan konsep ketuhanan Filsafat Perenial, maka harus dibedakan antara pendekatan esoterik dan eksoterik. Pendekatan esoterik adalah pemahaman langsung tentang Tuhan melalui penyatuan seluruh potensi kemanusiaan yang dikenal sebagai "jalan" mistik. Areanya meliputi hikmah transendental dan kesatuan mistik, kesadaran yang bersumber dari pengetahuan secara langsung. Hal-hal esoterik melekat di dalam jiwa secara tiba-tiba sebagai karunia Tuhan yang merupakan hasil dari pengalaman kejiwaan (Kuswanjono, 2006: 8). Sementara pendekatan eksoterik: berfungsi sebagai dasar pijakan pemahaman tentang Tuhan berdasarkan perkataan Tuhan tentang Diri-Nya sendiri yaitu melalui wahyu (Kuswanjono, 2006: 8).

Ini berarti seluruh agama memilik hal yang sama dalam aspek esoterik, namun di dalam menerjemahkan aspek esoterik itu manusia akhirnya tiba pada aspek eksoterik yang didasarkan pada penyataan Tuhan atas Diri-Nya melalui Wahyu. Atau seperti yang disimpulkan Saputra (Saputra, 2012: 113) bahwa "perbedaan antara agama hanya pada dataran eksoterik, yang sejatinya memiliki kesatuan transendental dalam dataran esoterik." Schuon (Schuon, 1993: 25-26) memberikan ilustrasi perbedaan antara Esoterik dan Eksoterik secara sederhana.

\section{REALITAS ULTIM/ABSOLUT}

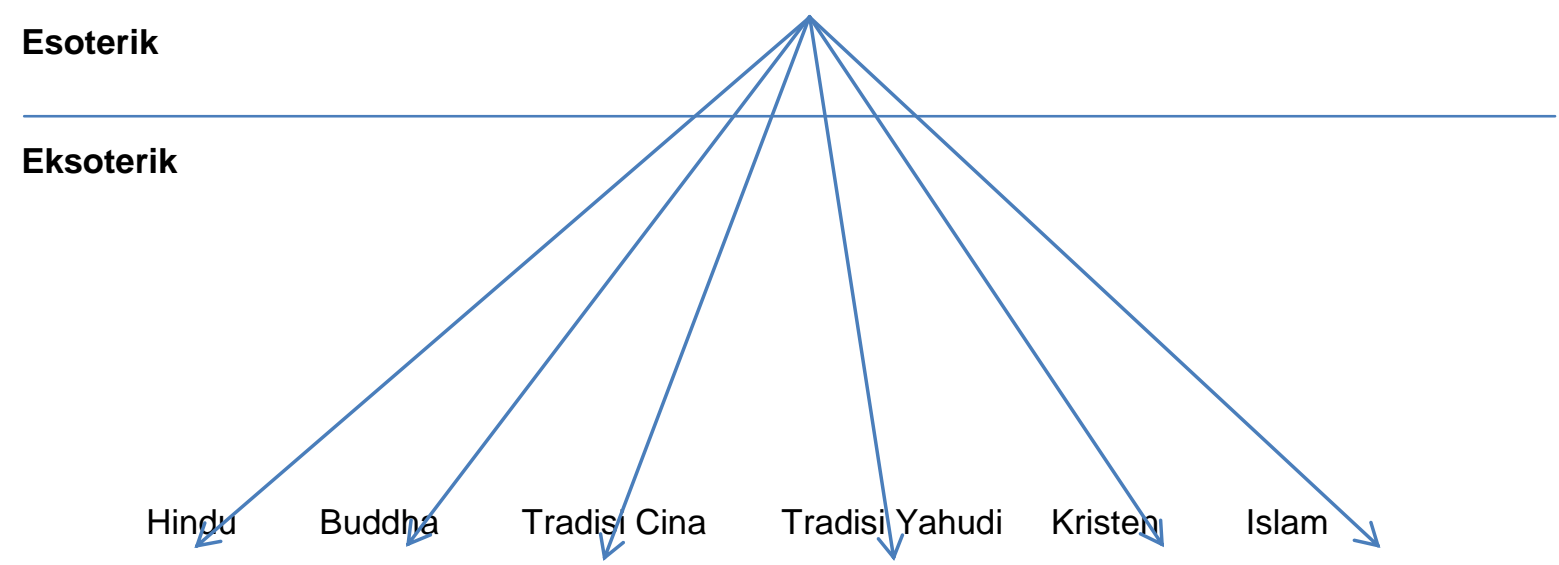


Penjelasannya adalah, "garis pemisah tadi bersifat horizontal dan hanya ditarik satu kali membelah berbagai agama yang menarik garis pemisah antara yang esoteris dengan yang eksoteris dan segera merasakan bahwa kita berada dalam suasana yang lain. Perbedaan dasar bukanlah agama yang satu dan agama yang lain. Dapat dikatakan garis pemisah itu bukannya membagi perwujudan historis yang besar dari agama-agama secara vertikal: agama Hindu dari agama Budha, dari agama Kristen, dari agama ditemui sepanjang sejarah. Di atas garis itu terletak paham esoterisme, sedangkan di bawahnya terletak paham eksoterisme" (Smith, 1993: 9-10).

Pada bagian akhir ini dibahas dua hal sebagai refleksi Konsep Ketuhanan kedua agama tersebut dalam pandangan Filsafat Perenial. Hal pertama adalah menyangkut penggunaan kata "Allah" yang merujuk kepada Zat Absolut. Hal yang penting adalah kedua agama tersebut mengakui adanya Sang Pencipta yang menciptakan dari yang tidak ada menjadi ada. Sang Pencipta ini disebut atau dipanggil Allah. Allah tidak diciptakan; la ada dengan sendirinya. Ia adalah Zat (Roh). Kedua agama juga memiliki persamaan pemahaman akan sifat-sifat Allah itu sendiri.

Kata Allah dalam bahasa Arab memiliki kerabat dalam bahasa Semit lainnya seperti Elah dalam bahasa Aram, El dalam bahasa Kanaan dan Elohim dalam bahasa Ibrani. Kata Allah (elohim) dalam Alkitab bagi orang Kristen bukanlah nama dari Sang Pencipta yang disembah. Mengapa? Karena kata Allah (elohim) dalam Alkitab digunakan bukan hanya kepada yang disembah oleh bangsa Israel namun juga kepada yang disembah oleh bangsa-bangsa kafir pada masa itu.

Dalam Alkitab, nama Allah (elohim) Pencipta ini adalah YAHWEH atau YHWH (dalam bahasa Indonesia diterjemahkan TUHAN). Sementara bagi agama Islam, kata Allah (secara harafiah berarti Sang Tuhan) cenderung atau sesungguhnya adalah nama Sang Pencipta yang disembah. Walaupun dalam Islam ada banya nama-nama Allah lainnya. Banyak diskusi yang terjadi terkait kata "Allah" sebagai nama Sang Pencipta bagi umat Muslim atau merujuk kepada gelar sang Pencipta secara umum atau nama dewa di tanah Arab. Oleh karena perdebatan ini, di beberapa tempat orang-orang Kristen menghindar bahkan ada yang dilarang untuk menggunakan kata "Allah" ketika menyebut Sang Pencipta.

Sekalipun diyakini bahwa Allah Yahudi, Kristen dan Islam sama, tentu tidak disimpulkan bahwa Tuhan semua agama sama. Dalam pengertian 'Universalisme' (pluralisme agama) disebutkan bahwa semua agama itu menyembah Tuhan yang sama (esoterik atau universal) namun melalui jalan-jalan yang berbeda (eksoterik atau partikular). Maka dalam perspektif Filsafat Perenial, Allah (YAHWEH) yang disembah oleh orang-orang Kristen adalah Allah yang sama yang disembah oleh umat-umat Muslim karena Dia adalah Sang Pencipta. Alasan yang lain adalah karena kedua agama tersebut mempercayai Allah (Tuhan) yang sama yang disembah baik oleh nabi-nabi sebelum dan sesudah lbrahim. Bahkan kedua agama samasama mengaku sebagai agama Semawi (datang dari Langit) dan agama Abrahamik (satu keturunan) serta mengaku bahwa Kitab-Kitab Sucinya berasal dari Allah (Wahyu Tuhan). Satu ayat Al'quran menegaskan hal ini: "Dia (Allah) telah mensyariatkan bagi kamu tentang agama sebagaimana yang telah Dia pesankan kepada Nuh dan yang Kami wahyukan kepadamu serta Kami pesankan kepada Ibrahim, Musa, dan 'Isa adalah bahwa tegakkanlah olehmu agama dan janganlah kamu berpecah-belah mengenainya. Terasa berat bagi kaum musyrik apa yang engkau (Muhammad) serukan itu (Surat al-Syura [42] ayat 13).

Namun, sampai saat ini masih tetap banyak diskusi-diskusi atau perdebatan, baik yang pro maupun kontra, tentang: apakah Tuhan orang Kristen (Yahweh) sama dengan Tuhan (Allah SWT) orang Islam? Atau berbeda? Ikbal (Ikbal, 2015: 8) meringkaskan sebagai berikut: "Dalam Islam Dia adalah Tuhan Yang Maha Esa, Pencipta langit dan bumi, sama seperti dalam agama Nasrani, dan Yang Maha Esa itu disebut oleh umat Yahudi dengan Yehovah, disebut oleh orang-orang Yunani kuno dengan Zeus, atau disebut oleh orang-orang India-Aria dengan Deus. Apa pun nama yang disandangkan kepada-Nya, semua umat beragama mengakui bahwa Dia tidak lain adalah Tuhan Yang Mutlak, Pencipta dan Pengatur alam semesta." Al'Quran juga memberikan dukungan kepada pemahaman ini: "Sesungguhnya orang-orang yang beriman, orang-orang Yahudi, orang-orang Nasrani, dun orang-orang Sabea, siapa saja di antara mereka yang benar-benar beriman kepada Allah dan hari kemudian, dan beramal saleh, mereka akan menerima pahala dari Tuhan mereka, tidak ada kekhawatiran terhadap mereka, dan tidak [pula] mereka bersedih hati." (Surat al-Baqarah [2] ayat 62).

Untuk menjelaskan persoalan ini, dalam Alkitab ada satu peristiwa ketika Rasul Paulus berada di Atena, lalu ia melihat bahwa kota itu penuh dengan patung-patung berhala. Lalu 
Paulus bertemu dengan orang-orang Atena tersebut dan berdiri di atas Areopagus sambil berkata: "Hai orang-orang Atena, aku lihat, bahwa dalam segala hal kamu sangat beribadah kepada dewa-dewa. Sebab ketika aku berjalan-jalan di kotamu dan melihat-lihat barang-barang pujaanmu, aku menjumpai juga sebuah mezbah dengan tulisan: 'Kepada Allah yang tidak dikenal.' Apa yang kamu sembah tanpa mengenalnya, itulah yang kuberitakan kepada kamu. Allah yang telah menjadikan bumi dan segala isinya, la, yang adalah Tuhan atas langit dan bumi, tidak diam dalam kuil-kuil buatan tangan manusia, dan juga tidak dilayani oleh tangan manusia, seolah-olah la kekurangan apa-apa, karena Dialah yang memberikan hidup dan nafas dan segala sesuatu kepada semua orang" (Kisah Para Rasul 17:22-25). Dari pernyataan ayatayat di atas Paulus mengakui bahwa orang Atena, selain menyembah dewa-dewa mereka yang tidak berdasarkan kepada kebenaran Firman Tuhan, mereka juga menyembah Allah Pencipta langit dan bumi. Itu adalah "Allah yang tidak dikenal" orang Atena yang sedang diberitakan oleh rasul Paulus. Jadi, ada kemungkinan agama-agama non semawi atau non-Abrahamik juga menyembah Sang Pencipta selain dewa-dewa mereka lainnnya. Ini juga berlaku ketika berbicara tentang Allah yang disembah agama Kristen adalah Allah yang sama yang disembah agama Islam (pendekatan esoterik). Namun cara memahami Allah itu sudah barang tentu berbeda-beda (pendekatan Eksoterik)

Hal kedua adalah pemahaman kata "esa." Dalam bahasa Ibrani kata esa adalah echad sementara dalam bahasa Arab adalah Ahad atau Ahadun. Sudah banyak diskusi tentang konsep Allah Yang Maha Esa ini baik dalam lingkungan Kekristenan maupun antara Kristen dan Muslim. Bahkan pembahasan penggunaan kata Ahad atau Ahadun dalam Al'Quran dan pemakaiannya secara umum juga terjadi. Secara umum, orang Kristen memahami kata esa (echad) bukan merujuk kepada angka (kuantitas) namun konsep kesatuan (kualitas). Sebaliknya, agama Islam meyakini bahwa kata "esa" (Ahad/ahadun) menyatakan angka (tunggal). Di sinilah letak persoalan itu. Maka dalam perspektif Filsafat Perenial, konsep Allah Esa adalah pendekatan esoterik. Sementara bagaimana manusia memahami Allah Esa itu bergantung wahyu yang diterima melalui Kitab Suci masing-masing dan interpretasi atas wahyu itu sendiri (eksoterik).

Ini dapat dipahami secara jelas dalam Pancasila. Sila Pertama berbunyi: "Ketuhanan Yang Maha Esa" sementara semboyan Bangsa Indonesia adalah: "Bhinnneka Tunggal Ika." Para pendiri negara ini memahami betul arti esa dan eka. Kata eka selalu dikaitkan kepada halhal yang bukan Tuhan sementara kata esa hanya digunakan kepada Tuhan. Bilamana kata "esa" diartikan angka (tunggal) maka hanya agama Islamlah yang boleh ada di Negara Indonesia ini. Namun para pendiri negara Indonesia memahami kata esa berbeda. Tuhan Yang Maha Esa dalam pemahaman para pendiri negara Indonesia adalah Tuhan yang tidak ada bandingannya. Tuhan yang kekal, Tuhan yang abadi. Itu sebabnya agama Kristen, Hindu, Budha, dan Kong Fu Cu bisa tumbuh di Negara Indonesia oleh karena masing-masing agama ini juga mengakui dan menyembah Allah Yang Esa (esoterik) yang tiada bandingannya dengan pemahaman dan caranya masing-masing (eksoterik).

\section{Kesimpulan}

Konsep Ketuhanan (eksoterik) yang dimiliki oleh masing-masing agama di dunia ini boleh saja memiliki beberapa persamaan atau mungkin berbeda sama sekali. Ini juga terjadi di antara agama-agama Semawi atau Abrahamik yaitu Yahudi, Kristen dan Islam.

Namun dalam pemahaman eksoteriknya, maka agama Kristen dan agama Islam memiliki pemahaman yang berbeda tentang Tuhan Yang Maha Esa itu. Bagi agama Kristen Allah yang Esa itu terdiri dari tiga Pribadi yaitu Bapa, Anak, dan Roh Kudus. Esa yang dipahami oleh agama Kristen adalah kesatuan (kualitas) bukan tunggal (kuantitas). Sementara agama Islam memahami Allah Yang Maha Esa adalah Allah yang tunggal (kuantitas).

Yang kedua adalah penggunaan kata Allah itu sendiri. Agama Kristen menggunakan kata Allah sebagai gelar kepada YAHWEH Sang Pencipta langit dan bumi. Karena dalam Alkitab, kata Allah (elohim) digunakan baik kepada Sang Pencipta yang disembah bangsa Israel maupun kepada dewa-dewa yang disembah oleh bangsa-bangsa lain di masa itu. Sementara agama Islam mengakui bahwa Allah adalah Nama Sang Pencipta itu sendiri.

Di sinilah perlunya Filsafat Perenial yang merupakan Filsafat Abadi karena dalam pemikiran Filsafat Perenial, KEBENARAN (TRUTH) itu satu (esoterik), dan masing-masing agama memiliki dan mengajarkan kebenaran (truth) sesuai dengan wahyu yang diterima (eksoterik). Dalam konteks ini, Filsafat Perenial tidak bertujuan untuk menyamakan semua agama atau bahkan mendirikan hanya satu agama di dunia. Tujuan Filsafat Perenial adalah 
agar masing-masing agama dan para pemeluknya boleh menghargai bagaimana setiap agama menjalankan dan mengekpresikan imannya sesuai dengan wahyu yang diterima (eksoterik).

Maka, dalam refleksi konsep Ketuhanan baik agama Kristen dan Agama Islam dalam pemikiran Filsafat Perenial yang telah dibahas, perbedaan yang ada bukanlah untuk dipersoalkan atau diperdebatkan sehingga semakin melebar atau meruncing karena memang hingga saat ini belum ada kesimpulan yang pasti tentang perbedaan-perbedaan tersebut. Dasarnya adalah kedua agama tersebut sama-sama menyembah Sang Pencipta; sama-sama mengaku sebagai agama Semawi dan agama Abrahamik dan menerima Kitab Suci-nya masing-masing dari Allah

\section{Daftar Pustaka}

Al-Akkad, Abbas Mahmoud. 1981. Ketuhanan: Sepanjang Ajaran Agama-agama dan Pemikiran Manusia. Jakarta: Bulan Bintang.

As-Shadiqi, Muhammad. 2003. Membela Tuhan: Argumen Filosofis, Teologis dan Ilmiah. Yogyakarta: Qalam.

Baharudin, M. "Konsepsi Ketuhanan Sepanjang Sejarah Manusia." Jurnal Al-AdYaN. Vol. 9. No. 1. Januari - Juni 2014. Hal. 35-58. https://media.neliti.com/media/ publications/177914-ID-konsepsi-ketuhanan-sepanjang-sejarah-man.pdf. Diakses tanggal 29 Mei 2018.

Brooke, George J. 1997. New International Dictionary of Old Testament Theology and Exegesis. Gen. Ed. Willem A. VanGemeren. Vol. 2. Grand Rapids, Michigan: Zondervan.

Danim, Sudarwan. 2002. Menjadi Peneliti Kualitatif. Bandung: Pustaka Setia.

Gazalba, Sidi. 1976. IImu Islam 1: Asas Ajaran Islam: Pembahasan Ilmu dan Filsafat Tentang Rukun Iman. Jakarta: Bulan Bintang.

Huijbers, Theo. 1992. Mencari Allah: Pengantar ke dalam Filsafat Ketuhanan. Yogyakarta: Kanisius.

https://pustakauinib.ac.id/repository/files/original/c49cdfb8d200366e2afa6f444f1471a1.pdf. Diakses tanggal 29 Mei 2018.

Ikball, M. 2015. "Memahami Agama Dengan Pendekatan Esoterik." Kalam: Jurnal Studi Agama dan Pemikiran Islam. Volume 9, No. 1, Juni 2015. Diakses dari: http://ejournal.radenintan.ac.id/index.php/KALAM/article/download/317/174. Diakses tanggal 9 Oktober 2018.

Jenson, P. P. 1997. New International Dictionary of Old Testament Theology and Exegesis. Gen. Ed. Willem A. VanGemeren. Vol. 1. Grand Rapids, Michigan: Zondervan, 1997.

Kaelan, MS. 2005. Metode Penelitian Kualitatif Bidang Filsafat. Yogyakarta: Paradigma.

Kuswanjono, Arqom. 2006. Ketuhanan dalam Telaah Filsafat Perenia: Refleksi Pluralisme Agama di Indonesia. Yogyakarta: Badan Penerbitan Filsafat UGM.

Puar, Yusuf A. 1977. Panca Agama di Indonesia. Jakarta: Pustaka Antara. 
Rasjidi, H. M. 1974. Empat Kuliah Agama Islam pada Perguruan Tinggi. Jakarta: Bulan Bintang.

Saputra, Riki. 2012. Tuhan Semua Agama: Perspektif Filsafat Perennial Seyyed Hossein Nasr. Yogyakarta: Lima.

Schuon, Frithjof. 1993. Islam dan Filsafat Perennial. Diterjemahkan oleh Rahmani Astuti. Bandung: Mizan.

Smith, Huston. 1993. "Kata Pengantar." Dalam Frithjof Schuon. Mencari Titik Temu Agamaagama. Bandung: Mizan. . 1995. Agama-agama Manusia. Jakarta: Yayasan Obor Indonesia.

Trueblood, David. 1965. Filsafat Agama. Diterjemahkan oleh H. M. Rasjidi. Jakarta: Bulan Bintang.

Verkuyl, J. 1961. Etika Kristen: Kapita Selekta. Jakarta: BPK Gunung Mulia. 